\title{
Anti-inflammatory action of seed extract and polymeric nanoparticles of Syzygium cumini in diabetic rats infected with Candida albicans
}

\author{
Paula E. R. Bitencourt ${ }^{1}$, Lariane O. Cargnelutti ${ }^{1}$, Carolina S. Stein ${ }^{1}$, Raquel Lautenchleger ${ }^{1}$, Luana M. Ferreira ${ }^{2}$, \\ Manuela Sangoi ${ }^{1}$, Aline Boligon ${ }^{2}$, Marta M. M. F. Duarte ${ }^{4}$, Rafael N. Moresco ${ }^{1}$, Letícia Cruz ${ }^{2}$, Régis A. Zanette ${ }^{5}$, \\ Sydney H. Alves ${ }^{3}$, Maria Beatriz Moretto ${ }^{1 *}$ \\ ${ }^{1}$ Departamento de Análises Clínicas e Toxicológicas, Centro de Ciências da Saúde, Programa de Pós-Graduação em Ciências Farmacêuticas, Universidade \\ Federal de Santa Maria, Santa Maria, RS, Brazil. ${ }^{2}$ Departamento de Farmácia Industrial, Centro de Ciências da Saúde, Programa de Pós-Graduação em \\ Ciências Farmacêuticas, Universidade Federal de Santa Maria, Santa Maria, Brazil. ${ }^{3}$ Departamento de Microbiologia, Centro de Ciências da Saúde, \\ Programa de Pós-Graduação em Ciências Farmacêuticas, Universidade Federal de Santa Maria, Santa Maria, Brazil. ${ }^{4}$ Universidade Luterana do Brasil, \\ Santa Maria, Brazil. ${ }^{5}$ Programa de Pós-Graduação em Ciências Biológicas: Farmacologia e Terapêutica, Universidade Federal do Rio Grande do Sul, Porto \\ Alegre, Brazil.
}

\begin{tabular}{|c|c|}
\hline ARTICLE INFO & ABSTRACT \\
\hline Article history: & \multirow{10}{*}{$\begin{array}{l}\text { The role of Syzygium cumini against chronic complications of Diabetes mellitus (DM), such as fungal infection } \\
\text { and inflammation, has been poorly explored. Here, we evaluated the treatment with } S \text {. cumini aqueous seed } \\
\text { extract (ASc, } 100 \mathrm{mg} / \mathrm{Kg} \text { ) and polymeric nanoparticles containing ASc (NPASc, 100mg/Kg) in diabetic rats } \\
\text { infected or not by Candida albicans (CA). Male Wistar rats were divided in: control; DM; CA; CA+ASc; } \\
\text { CA+NPASc; DM+CA; DM+CA+ASc; and DM+CA+NPASc. Rats were daily treated for } 21 \text { days, when } \\
\text { glycemic profile, ectonucleotidase (NTPDase and 5'-NT), adenosine deaminase (ADA), acetylcholinesterase } \\
\text { (AChE) and dipeptidyl peptidase IV (DPP-IV) activities and nitric oxide (NO) and cytokine levels were } \\
\text { analyzed in serum, platelets, lymphocytes and tissues. The results showed that NTPDase, 5'-NT and ADA } \\
\text { activities and NO, IL-1, IL-6, TNF- } \alpha \text { and IFN-y levels were increased in } C \text {. albicans, DM and DM+CA. The } \\
\text { treatment with ASc and NPASc decreased ectonucleotidase and AChE activities and NO levels. Both treatments } \\
\text { also prevented the increase in ADA activity and pro-inflammatory cytokines in cells and serum. In liver and } \\
\text { pancreas, NPASc decreased NO levels more efficiently than ASc. The modulation of ectoenzyme activities can } \\
\text { be one of the mechanisms by which } S \text {. cumini act on cytokines that affect the development of chronic } \\
\text { complications in DM. }\end{array}$} \\
\hline Received on: $16 / 07 / 2016$ & \\
\hline Revised on: 11/08/2016 & \\
\hline Acce & \\
\hline Available online: $31 / 01 / 2017$ & \\
\hline $\begin{array}{l}\text { Key words: } \\
\text { Diabetes model; Candida }\end{array}$ & \\
\hline albicans infection; cytokines; & \\
\hline ectonucleotidases; Syzygium & \\
\hline cumini seeds; & \\
\hline nanotechnology. & \\
\hline
\end{tabular}

\section{INTRODUCTION}

Diabetes mellitus (DM), a disorder characterized by chronic hyperglycemia and impaired insulin signaling, generates metabolic changes and an inflammatory status that will eventually affect all body tissues (Boteanu et al., 2015). Several different immune deficits have been described in diabetic

\footnotetext{
* Corresponding Author

Maria Beatriz Moretto, Departamento de Análises Clínicas e Toxicológicas, Centro de Ciências da Saúde, Programa de PósGraduação em Ciências Farmacêuticas, Universidade Federal de Santa Maria, Santa Maria, RS, Brazil.Email: beatriz@smail.ufsm.br
}

patients, given that cell-mediated immunity seems to be particularly affected, including dysfunctions of white blood cells such as impaired leukocyte adherence, chemotaxis, oxidative burst and bactericidal activity (Fraga-Silva et al., 2015). The cholinergic anti-inflammatory pathway mediated by acetylcholine (ACh) regulates immune responses to pathogens (Borovikova et al., 2000), but the role of this pathway in infections is not well characterized. Moreover, pro-inflammatory mediators such as nitric oxide (NO) play an important role mediating various cellular signaling pathways and inducing pro-inflammatory and destructive effects, exerting antimicrobial action (Shahani and Sawa, 2011; Samarghandian et al., 2013). 
The association between diabetes and the prevalence of microbial infections such as those caused by fungi has also been reported (Joshi et al., 1999).

Disturbances in cell metabolism caused by DM can lead to changes in intra- and extracellular concentrations of adenine nucleotides and nucleosides. The extracellular metabolism of ATP, which is released in response to cellular stress or damage, to adenosine is usually mediated by a variety of enzymes such as triphosphate diphosphohydrolase (NTPDase), which also hydrolyzes ADP to adenosine.

Additionally, following hydrolysis of ATP to AMP, AMP is dephosphorylated by $5^{\prime}$-nucleotidase (5'-NT) to produce adenosine, which has anti-inflammatory and immunosuppressive functions (Schmatz et al., 2013). The extracellular concentrations of adenosine are regulated through the enzyme adenosine deaminase (ADA), which can also interact with membrane proteins such as dipeptidyl peptidase IV (CD26/DPP-IV) (Gorrell et al., 2001). This process is directly involved in T-cell activation (Kameoka et al., 1993).

Syzygium cumini L. Skeels, a traditional medicinal tropical plant of Myrtaceae family widely known as jambolan or jamun, possesses hypoglycemic, anti-inflammatory and antioxidant properties (for review, see Ayyanar et al., 2013). In Brazil, the most used parts of the plant are fruits, which are consumed fresh, and leaves (Vizzotto, 2008), whose infusion is used by the Southern population to treat DM and by quilombo communities to treat kidney, heart and hyperlipidemia (Da Silva et al., 2012). S. cumini is included in the List of Medicinal Plants of Interest for the Public Health System (Renisus) issued by the Brazilian Ministry of Health, which includes plants considered as potentially valuable for the generation of herbal medicines (Brasil, 2009).

Phenols and flavonoids present in high amounts in $S$. cumini are responsible for the several biological activities observed in vitro. However, these compounds do not have the same profile of activity in vivo. In this sense, polymeric nanoparticles offer a non-toxic and efficient carrier system for enhanced drug bioavailability within the cells, tissues, or both, besides the minimization of the degradation process (Samadder et al., 2012; Bonifácio et al., 2014).

Recently, our group demonstrated that polimeric nanoparticles containing an aqueous extract of $S$. cumini (NPASc) were able to maintain the antioxidant properties of the extract (ASc) and lack toxicity in Artemia salina and in rats, highlighting their potential in the treatment of DM and its complications (Bitencourt et al., 2016).

Previous studies from our group have investigated the effects S. cumini and adenosine in DM (De Bona et al., 2014; Bitencourt et al., 2015). Nonetheless, as there is paucity of data evaluating the effects of ASc and NPASc on the chronic complications of DM, including increased susceptibility to fungal infections, the present study was aimed: 1) to evaluate changes in cholinergic and purinergic systems in DM rats infected or not by
Candida albicans; 2) to evaluate whether ASc and NPASc have potential as anti-inflammatory and antifungal candidates.

\section{MATERIALS AND METHODS}

\section{Chemicals}

Ethyl acetate, methanol, acetonitrile and acetic, gallic, chlorogenic, caffeic and ellagic acids were purchased from Merck (Darmstadt, Germany). Polysorbate 80 (Tween $80^{\circledR}$ ), poly- $\varepsilon_{-}$ caprolactone (PCL, $85 \mathrm{~g} / \mathrm{mol}$ ), sorbitan monooleate (Span $80^{\circledR}$ ), adenosine, ATP, ADP, streptozotocin, catechin, epicatechin, quercetin, isoquercitrin, quercitrin, kaempferol and rutin reference standards were acquired from Sigma Chemical Co. (St. Louis, MO, USA). All other chemicals were of analytical grade and were obtained from standard commercial suppliers.

\section{ASc and NPASc preparation, characterization and phytochemical analysis}

S. cumini seeds were collected $\left(29^{\circ} 43^{\prime} 22^{\prime \prime S}\right.$ and 534' $47^{\prime \prime}$, Santa Maria, Rio Grande do Sul, Brazil) fresh, locally and they were cleaned, dried and powdered. They were identified by the Laboratory of Botanic and Pharmacognosy of the Federal University of Santa Maria and a voucher specimen (SMDB 14.001) was deposited in the Herbarium of the institution. ASc was prepared according to Prince et al. (1998). NPASc were prepared by the emulsification/evaporation solvent method described by Quintanar-Guerrero et al. (1998), with modifications according to Bitencourt et al. (2016).

The presence of 11 antioxidant compounds in ASc and NPASc, namely gallic, chlorogenic, caffeic and ellagic acids and catechin, epicatechin, quercetin, quercitrin, isoquercitrin, kaempferol and rutin was investigated by HPLC-DAD. Identification of these compounds was performed by comparing their retention time and UV absorption spectrum with those of the commercial standards. Reverse phase chromatography analyses were carried out under gradient conditions using a $\mathrm{C}_{18}$ column (4.6 $\mathrm{mm} \times 150 \mathrm{~mm}, 5 \mu \mathrm{m})$. The chromatography peaks were confirmed by comparing their retention time with those of reference standards and by DAD spectra (200 to $500 \mathrm{~nm})$. All chromatographic operations were carried out at ambient temperature and in triplicate. Calibration curves for each substance were: gallic acid, $\mathrm{Y}=13973 \mathrm{x}+1095.6(\mathrm{r}=0.9993)$; catechin, $\mathrm{Y}=$ $11840 \mathrm{x}+1178.2(\mathrm{r}=0.9998)$; epicatechin, $\mathrm{Y}=12542 \mathrm{x}+1412.7$ $(\mathrm{r}=0.9991)$; chlorogenic acid, $\mathrm{Y}=11864 \mathrm{x}+1252.8(\mathrm{r}=0.9994)$; caffeic acid, $\mathrm{Y}=13178 \mathrm{x}+1267.2(\mathrm{r}=0.9999)$; ellagic acid, $\mathrm{Y}=$ $12681 \mathrm{x}+1164.9(\mathrm{r}=0.9998)$; rutin, $\mathrm{Y}=13077 \mathrm{x}+1265.4(\mathrm{r}=$ 0.9992); isoquercitrin, $\mathrm{Y}=11927 \mathrm{x}+1306.2(\mathrm{r}=0.9996)$; quercitrin, $\mathrm{Y}=13470 \mathrm{x}+1293.7(\mathrm{r}=0.9994)$ and quercetin, $\mathrm{Y}=$ $12693 x+1176.0(r=0.9997)$. The limit of detection (LOD) and limit of quantification (LOQ) were calculated based on the standard deviation of the responses and the slope using three independent analytical curves. LOD and LOQ were calculated as 3.3 and $10 \sigma / \mathrm{S}$, respectively, where $\sigma$ is the standard deviation of 
the response and $\mathrm{S}$ is the slope of the calibration curve. For the determination of encapsulation efficiency (EE), free phenolic compounds were separated from the nanostructures by ultrafiltration (Bitencourt et al., 2016). The difference between the total and the free concentrations of compounds, determined in the nanostructures and in the ultrafiltrate, respectively, was calculated according to the equation: $\mathrm{EE}=$ Total content - Free content $/$ Total content x 100 .

\section{Animals}

Male albino Wistar rats (weighing 150-200 g) were housed in colony cages (six rats per cage). All animal experiments were conducted in accordance with principles for laboratory animal use and care, as described in the guidelines of the Ethics Committee for Animal Research of the Federal University of Santa Maria, which approved the experimental protocol ( ${ }^{\circ}$ 074/2014). All efforts were made to minimize the number of animals used and their suffering.

\section{Induction of DM, animal infection and experimental design}

DM type I was induced by the intraperitoneal administration of a single dose of streptozocin (STZ) $(60 \mathrm{mg} / \mathrm{kg})$ dissolved in freshly prepared $0.1 \mathrm{M}$ citrate buffer, $\mathrm{pH}$ 4.5. Control animals received only citrate buffer. Diabetic rats were allowed to drink $5 \%$ glucose solution overnight to overcome the drug-induced hypoglycemia and only diabetic rats with a fasting blood glucose level of at least $250 \mathrm{mg} / \mathrm{dl}$ were included in the experiment.

Inoculum was obtained from a clinical $C$. albicans strain grown for $20 \mathrm{~h}$ at $30{ }^{\circ} \mathrm{C}$. Yeast cells were harvested by centrifugation at $3000 \mathrm{rpm}$ for $10 \mathrm{~min}$, washed three times with sterile PBS, counted in a hemocytometer and resuspended in sterile PBS to the required inoculum concentration $\left(10^{5}\right.$ colony forming units $(\mathrm{CFU}) / \mathrm{mL})$. Fifteen days after DM induction, rats assigned to $C$. albicans infection were inoculated intraperitoneally with $0.2 \mathrm{ml}$ of yeast suspension (Fisher et al., 1989). This inoculum consistently infects $>90 \%$ of normal rats in this model.

ASc or NPASc were administered by gavage at a dose of $100 \mathrm{mg} / \mathrm{kg}$ (Bitencourt et al., 2015). Rats were divided into eight groups of six animals each, according to the following schematic timeline of the experimental design:

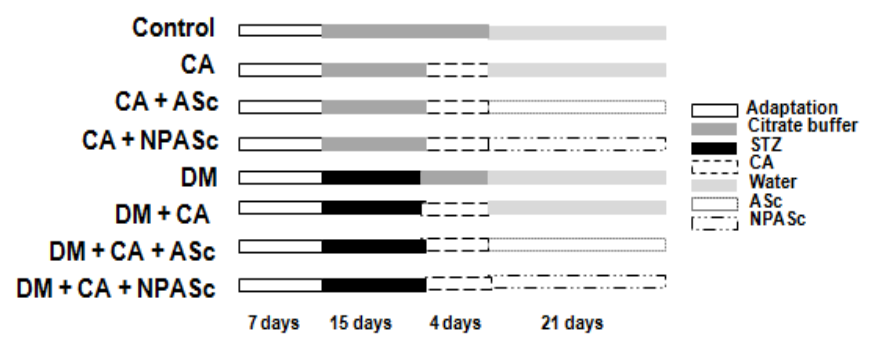

At day 21 of treatment, the rats were anesthetized with isoflurane, euthanized and the blood was collected by cardiac puncture. Samples of liver and kidney were rapidly dissected, weighed and placed on ice. Moreover, kidney and liver fragments were aseptically removed and $0.1 \mathrm{~g}$ of each organ was homogenized in sterile saline. Samples were cultured onto Sabouraud dextrose agar, incubated at $30{ }^{\circ} \mathrm{C}$ for $72 \mathrm{~h}$, and the number of yeasts was expressed as $\mathrm{CFU} / \mathrm{g}$ of tissue.

\section{Platelet preparation}

Platelet-rich plasma (PRP) was prepared by the method of Lunkes et al. (2003) and the protein concentration was measured by the method of Lowry et al. (1951), using bovine serum albumin as the standard.

\section{Lymphocyte isolation}

Rat lymphocytes were isolated from the spleen under aseptic conditions, as described by Sai Ram et al. (1997). The final cell suspension was resuspended in PBS (pH 7.4) and $3 \times 10^{6}$ cells $/ \mathrm{mL}$ were used for each analysis. The protein concentration was measured by the method of Lowry et al. (1951), using bovine serum albumin as the standard. Acetylcholinesterase (AChE) was determined in lymphocyte suspension by a modification of the spectrophotometric method of Ellman et al. (1961). The enzymatic activity was expressed in $\mu \mathrm{mol} \mathrm{AcSCh} / \mathrm{h} / \mathrm{mg}$ of protein.

\section{Biochemical and inflammatory analyses}

Serum obtained by centrifugation was analyzed spectrophotometrically for glucose and fructosamine levels using commercial diagnostic kits (Labtest Diagnóstica, Brazil). Plasmatic insulin was measured by radioimmunoassay (DPC Coata-Count kit, CA, USA) in a gamma counter. Serum inflammatory cytokine quantification was assessed by ELISA using commercial kits for interferon (IFN)- $\gamma$, tumor necrosis factor (TNF)- $\alpha$, interleukin (IL)-1, IL-6 and IL-10 (R\&D Systems, MN, USA), according to manufacturer's instructions.

\section{DPP-IV activity}

DPP-IV activity was measured spectrophotometrically in serum and lymphocyte suspension by the method of Jarmolowska et al. (2007) and Schön et al. (1984), respectively. Samples were incubated with Gly-Pro p-nitroanilide p-toluenesulfonate for 120 min at $37{ }^{\circ} \mathrm{C}$. The reaction was stopped by adding $1 \mathrm{M}$ acetate buffer ( $\mathrm{pH} 4.5$ ). P-nitroanilide was used as standard and the values were expressed in U/l.

\section{NTPDase and 5'-NT activities}

The reaction medium used to assay ATP, ADP and AMP hydrolysis in rat platelets and serum was prepared as described by Lunkes et al. (2003) and Oses et al. (2004), respectively, and the inorganic phosphate $(\mathrm{Pi})$ released was measured as previously described (Chan et al., 1986). Enzyme activities were expressed as $\mathrm{nmol} \mathrm{Pi}$ released/min/mg of protein.

\section{ADA activity}

ADA activity in serum, platelets, lymphocytes and tissues (homogenized in $50 \mathrm{mM}$ PBS, $\mathrm{pH}$ 7) was estimated spectrophotometrically as previously described (Giusti and 
Galanti, 1984). The results were expressed as U/L in serum and $\mathrm{U} / \mathrm{L} / \mathrm{mg}$ of protein in lymphocytes and tissues. The protein concentration was measured by the method of Lowry et al. (1951).

\section{Oxide nitric (NO) measurement}

NO was determined indirectly by quantifying serum, lymphocytes and tissues (homogenized in $10 \mathrm{mM}$ Tris- $\mathrm{HCl}$ buffer solution, $\mathrm{pH}$ 7.4). NO was measured by the modified Griess method using the Cobas Mira ${ }^{\circledR}$ automated analyzer (Tatsch et al., 2011). The results were expressed as $\mu \mathrm{M} / \mathrm{L}$.

\section{Statistical analysis}

Data were analyzed by one-way analysis of variance (ANOVA) followed by Duncan's post hock test using Statistica 6.0 software (StatSoft. Inc., USA). The limit of statistical significance was set at $\mathrm{p}<0.05$. The results were expressed as mean \pm SEM.

\section{RESULTS}

\section{Characterization of NPASc}

The chromatographic profiles of NPASc showed that nanoencapsulation did not alter the phenolic composition of ASc (Fig. 1A) and the results of encapsulation efficiency showed that almost $100 \%$ of phenolic compounds were entrapped within the particle (Fig. 1B). Nanoparticles showed average diameters lower than $200 \mathrm{~nm}$ and PDI less than 0.2, which indicates a narrow distribution (data not shown).

\section{Biochemical and immunological parameters}

As expected, there was an increase in the levels of glucose, fructosamine and a decrease in the levels of insulin in DM and $\mathrm{DM}+\mathrm{CA}$ groups when compared with the control group (Table 1). The administration of $\mathrm{ASc}(\mathrm{DM}+\mathrm{CA}+\mathrm{ASc})$ attenuated these levels, but did not prevent the decrease of insulin levels when compared to DM+CA. NPASc (DM+CA+NPASc) decreased fructosamine and glucose levels and avoided the decrease of insulin levels when compared with DM+CA $(\mathrm{p}<0.01)$. Levels of the pro-inflammatory cytokines IL-1, IL-6, TNF- $\alpha$ and INF- $\gamma$ were increased in DM, CA and mainly in DM+CA when compared to control $(\mathrm{p}<0.01)$. ASc $(\mathrm{CA}+\mathrm{ASc})$ and NPASc $(\mathrm{DM}+\mathrm{CA}+\mathrm{NPASc})$ were able to reduce these levels when compared to respective controls (CA and DM+CA). Furthermore, we observed a decrease in IL10 levels in DM, CA and DM+CA when compared to control. Interestingly, ASc did not affect this parameter, but NPASc were able to increase IL10 levels in CA+NPASc and $\mathrm{DM}+\mathrm{CA}+\mathrm{NPASc}$, in comparison to the respective controls. DPPIV activity was not altered.
A

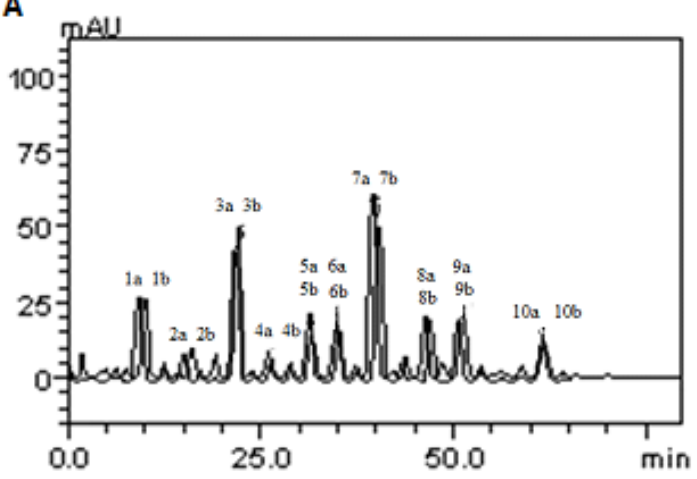

B

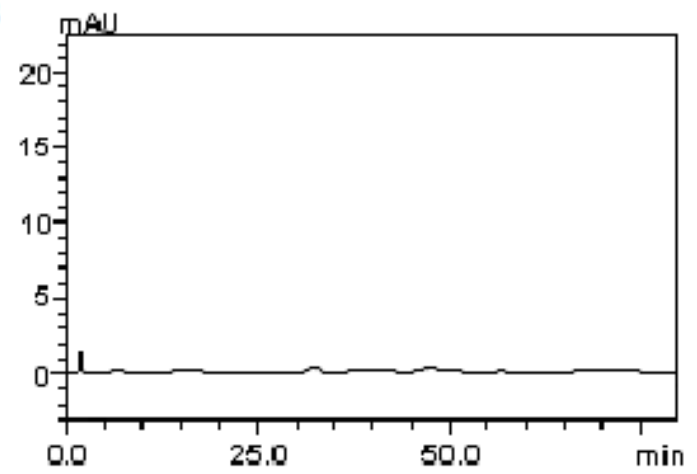

\begin{tabular}{ccc}
\hline Compounds & AS (a) $\mathbf{~ m g} / \mathbf{g}$ & NPASc (b) $\mathbf{~ m g} / \mathbf{g}$ \\
\hline Gallic acid & $10.72 \pm 0.002$ & $10.08 \pm 0.01$ \\
Catec hin & $2.26 \pm 0.003$ & $2.23 \pm 0.02$ \\
Chlorogenic & $5.57 \pm 0.001$ & $5.49 \pm 0.03$ \\
Caffeic acid & $2.61 \pm 0.014$ & $2.08 \pm 0.01$ \\
Ellagic acid & $2.08 \pm 0.007$ & $2.01 \pm 0.01$ \\
Epic atechin & $2.85 \pm 0.005$ & $2.74 \pm 0.02$ \\
rutin & $7.75 \pm 0.012$ & $7.65 \pm 0.03$ \\
Isoquercitrin & $5.94 \pm 0.003$ & $4.92 \pm 0.01$ \\
Querc etin & $2.83 \pm 0.009$ & $2.76 \pm 0.02$ \\
Kaempferol & $3.76 \pm 0.015$ & $2.30 \pm 0.01$ \\
\hline
\end{tabular}

Fig. 1: HPLC chromatogram obtained from ASc, NPASc (A) and EE (B).

Gallic acid (peak 1a and b), catechin (peak 2a and b), chlorogenic acid (peak 3a and b), caffeic acid (peak 4a and b), ellagic acid (peak 5a and b), epicatechin (peak $6 \mathrm{a}$ and b), rutin (peak 7a and b), isoquercitrin (peak 8a and b), quercetin (peak 9a and b) and kaempferol (peak 10a and b). ASc, aqueous seed extract of S. cumini; NPASc, nanoparticle suspension containing ASc. 
Table 1: Effect of the treatment with ASc and NPASc on serum biochemical and immunological parameters in rats.

\begin{tabular}{|c|c|c|c|c|c|c|c|c|c|}
\hline Groups & Glucose & Fructosamin & Insulin & DPPIV & IL1 & IL6 & TNF- $\alpha$ & IFN-y & IL10 \\
\hline Control & $83.25 \pm 2.58 b$ & $0.89 \pm 0.06 \mathrm{~b}$ & $0.34 \pm 0.02 \mathrm{a}$ & $33.19 \pm 2.34 \mathrm{a}$ & $36.50 \pm 2.02 d$ & $43.75 \pm 1.49 \mathrm{~d}$ & $59.00 \pm 1.87 \mathrm{e}$ & $74.75 \pm 2.28 \mathrm{e}$ & $96.00 \pm 2.34 \mathrm{a}$ \\
\hline $\mathrm{CA}$ & $83.75 \pm 6.90 \mathrm{~b}$ & $33 \pm 0.11 b$ & $0.39 \pm 0.02 \mathrm{a}$ & $35.65 \pm 3.69 a$ & $130.0 \pm 5.46 \mathrm{ab}$ & $136.0 \pm 3.24 \mathrm{~b}$ & $158.3 \pm 1.49 \mathrm{~b}$ & $209.5 \pm 6.06 \mathrm{a}$ & $59.50 \pm 2.50 \mathrm{~cd}$ \\
\hline $\mathrm{CA}+\mathrm{ASc}$ & $90.05 \pm 4.53 b$ & $0.86 \pm 0.10 b$ & $0.39 \pm 0.02 \mathrm{a}$ & $34.34 \pm 3.82 \mathrm{a}$ & $99.75 \pm 0.85 c$ & $113.0 \pm 1.95 \mathrm{e}$ & $137.3 \pm 1.79 f$ & $187.8 \pm 5.61 \mathrm{c}$ & $66.50 \pm 2.25 \mathrm{c}$ \\
\hline $\mathrm{CA}+\mathrm{NPASc}$ & $90.50 \pm 1.91 b$ & $1.06 \pm 0.03 b$ & $0.35 \pm 0.02 \mathrm{a}$ & $33.16 \pm 3.89 a$ & $89.00 \pm 0.91 \mathrm{c}$ & $101.0 \pm 2.48 \mathrm{ce}$ & $127.0 \pm 2.55 \mathrm{df}$ & $177.8 \pm 6.14 \mathrm{c}$ & $79.50 \pm 2.25 b$ \\
\hline $\mathrm{DM}$ & $358.2 \pm 18.89 \mathrm{a}$ & $2.15 \pm 0.13 \mathrm{a}$ & $0.17 \pm 0.01 b$ & $37.86 \pm 3.13 \mathrm{a}$ & $86.75 \pm 3.70 \mathrm{c}$ & $93.25 \pm 3.27 \mathrm{c}$ & $121.8 \pm 2.32 \mathrm{~d}$ & $126.0 \pm 2.04 \mathrm{~d}$ & $66.50 \pm 2.72 \mathrm{c}$ \\
\hline $\mathrm{DM}+\mathrm{CA}$ & $346.50 \pm 14.99 a$ & $2.04 \pm 0.27 \mathrm{a}$ & $0.16 \pm 0.01 b$ & $39.82 \pm 3.95 \mathrm{ab}$ & $149.8 \pm 6.29 \mathrm{e}$ & $169.3 \pm 4.85 \mathrm{a}$ & $189.3 \pm 6.11 \mathrm{a}$ & $216.8 \pm 8.23 a$ & $51.00 \pm 2.04 \mathrm{~d}$ \\
\hline $\mathrm{DM}+\mathrm{CA}+\mathrm{ASc}$ & $180.2 \pm 8.75 c$ & $1.07 \pm 0.10 \mathrm{~b}$ & $0.18 \pm 0.02 b$ & $41.04 \pm 3.05 b$ & $140.3 \pm 5.96 \mathrm{abe}$ & $149.0 \pm 7.03 b$ & $175.5 \pm 7.63 b$ & $203.0 \pm 9.11 \mathrm{a}$ & $54.50 \pm 2.10 \mathrm{~d}$ \\
\hline $\mathrm{DM}+\mathrm{CA}+\mathrm{NPASc}$ & $153.10 \pm 8.83 \mathrm{~d}$ & $1.02 \pm 0.14 \mathrm{~b}$ & $0.37 \pm 0.03 \mathrm{a}$ & $44.47 \pm 2.24 \mathrm{~b}$ & $127.0 \pm 6.33 b$ & $141.5 \pm 6.34 b$ & $166.8 \pm 7.71 \mathrm{~b}$ & $206.0 \pm 1.68 \mathrm{a}$ & $65.75 \pm 1.75 c$ \\
\hline
\end{tabular}

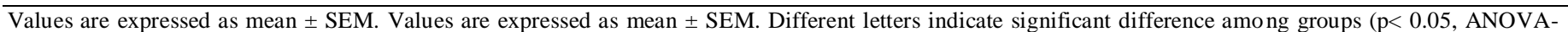

Duncan's test). Glucose (mg/dL); fructosamine (mmol/L); insulin (ng/mL); DPP-IV (U/L); IL1, IL6, IL10 and TNF- $\alpha$ (pg/mL); IFN- $\gamma$ ( $\mu$ g/mL).

Table 2: Effect of the treatment with ASc and NPASc on biochemical parameters in lymphocyte suspension.

\begin{tabular}{|c|c|c|c|c|}
\hline Groups & ADA & DPPIV & AChE & NOx \\
\hline Control & $2.52 \pm 0.15 \mathrm{e}$ & $104.00 \pm 4.91 \mathrm{c}$ & $0.67 \pm 0.04 b$ & $57.68 \pm 4.75 d$ \\
\hline $\mathrm{CA}$ & $6.59 \pm 0.22 b$ & $153.20 \pm 6.54 \mathrm{a}$ & $0.76 \pm 0.03 b$ & $239.10 \pm 10.72 b$ \\
\hline $\mathrm{CA}+\mathrm{ASc}$ & $4.65 \pm 0.33 c$ & $140.50 \pm 5.47 \mathrm{ab}$ & $0.76 \pm 0.05 b$ & $264.70 \pm 8.68 b$ \\
\hline $\mathrm{CA}+\mathrm{NPASc}$ & $2.73 \pm 0.25 \mathrm{e}$ & $154.40 \pm 9.49 \mathrm{a}$ & $0.78 \pm 0.08 b$ & $248.00 \pm 12.24 b$ \\
\hline DM & $7.30 \pm 0.54 b$ & $131.30 \pm 2.56 \mathrm{~b}$ & $1.13 \pm 0.09 \mathrm{a}$ & $230.10 \pm 12.69 b$ \\
\hline $\mathrm{DM}+\mathrm{CA}$ & $6.24 \pm 0.11 b$ & $132.50 \pm 4.76 b$ & $1.11 \pm 0.07 \mathrm{a}$ & $237.00 \pm 12.47 b$ \\
\hline $\mathrm{DM}+\mathrm{CA}+\mathrm{ASc}$ & $5.13 \pm 0.39 c$ & $125.70 \pm 7.36 b$ & $0.65 \pm 0.01 b$ & $135.90 \pm 7.41 \mathrm{c}$ \\
\hline $\mathrm{DM}+\mathrm{CA}+\mathrm{NPASc}$ & $3.30 \pm 0.37 \mathrm{~d}$ & $128.90 \pm 10.02 b$ & $0.73 \pm 0.01 b$ & $138.3 \pm 7.22 \mathrm{c}$ \\
\hline
\end{tabular}

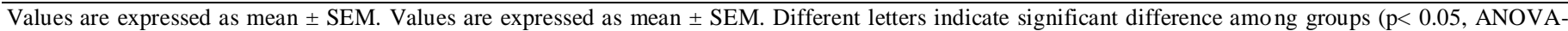
Duncan's test). ADA (U/L/mg of protein); DPPIV (U/L); NOx ( $\mu \mathrm{mol} / \mathrm{L})$; AChE (umol AcSCh/h/mg of protein).

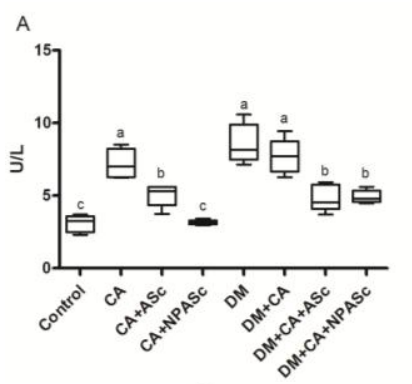

D

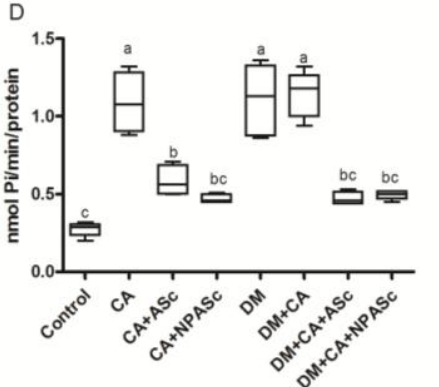

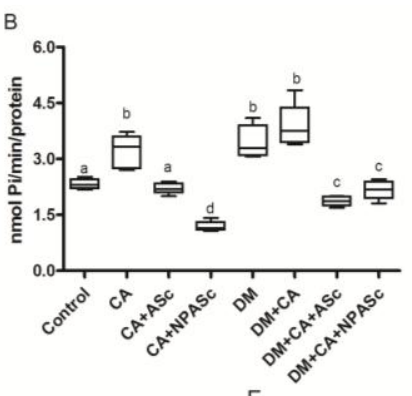
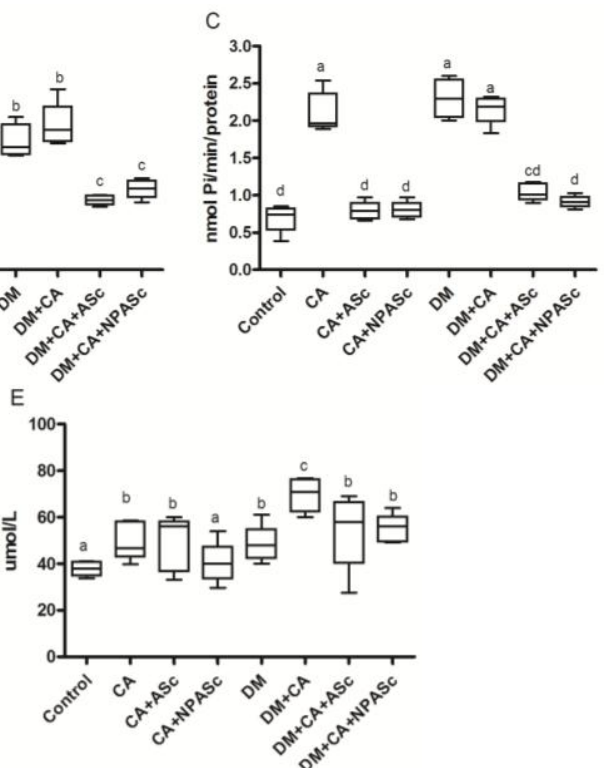

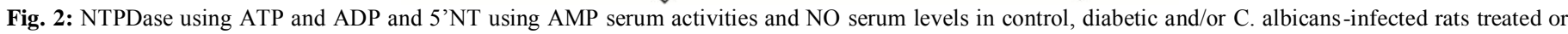

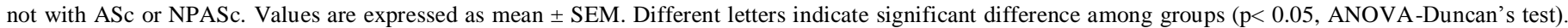
$\mathrm{A}=\mathrm{ADA}(\mathrm{U} / \mathrm{L}) ; \mathrm{B}=\mathrm{AMP}, \mathrm{C}=\mathrm{ADP}(\mathrm{nmol} \mathrm{Pi} / \mathrm{min} /$ protein); $\mathrm{D}=\mathrm{ATP}(\mathrm{nmol} \mathrm{Pi} / \mathrm{min} /$ protein) and $\mathrm{E}=\mathrm{NO}(\mu \mathrm{mol} / \mathrm{L})$

\section{Biochemical parameters in lymphocyte suspension}

Table 2 shows an increase in lymphocytic ADA, DPPIV and AChE activities and in NO levels in DM and DM+CA rats, when compared to control. The administration of ASc and NPASc prevented the increase in these values, except for DPPIV activity in comparison with $\mathrm{DM}+\mathrm{CA}$. Moreover, it was observed an increase in ADA and DPPIV activity and in NO levels in $C$. albicans-infected rats. Only ADA activity was reversed by the treatment with ASc and NPASc in these animals.

\section{ADA, 5'-NT and NTPDase activities and NO levels in serum}

An increase in serum ADA, 5'-NT and NTPDase activities was observed in DM and $\mathrm{DM}+\mathrm{CA}$ when compared to control. ASc (DM+CA+ASc) and NPASc (DM+CA+NPASc) were able to decrease these activities when compared to DM+CA (Fig. 2). The activities of these enzymes were also increased in CA group in relation to control, and once again, both treatments $(\mathrm{CA}+\mathrm{ASc}$ and $\mathrm{CA}+\mathrm{NPASc})$ effectively decreased ADA, 5'-NT and NTPDase activities when compared to CA.

NO levels were increased in DM $(\mathrm{p}<0.05)$ and CA $(\mathrm{p}<0.05)$ and an exacerbated increase was observed in $\mathrm{DM}+\mathrm{CA}$ $(p<0.01)$ in relation to control. The administration of ASc or NPASc reversed these levels when compared to DM+CA. Conversely, ASc did not affect NO levels in CA+ASc, but NPASc treatment $(\mathrm{CA}+\mathrm{NPASc})$ was able to reverse this parameter to near normalcy. 
Table 3: Effect of the treatment with ASc and NPASc on ADA activity and NOx levels in tissues.

\begin{tabular}{|c|c|c|c|c|c|c|}
\hline \multirow[t]{2}{*}{ Groups } & \multicolumn{2}{|c|}{ Kidney } & \multicolumn{2}{|c|}{ Liver } & \multicolumn{2}{|c|}{ Pancreas } \\
\hline & ADA & NOx & ADA & NOx & ADA & NOx \\
\hline Control & $37.72 \pm 3.72 \mathrm{~d}$ & $145.30 \pm 11.40 \mathrm{e}$ & $6.98 \pm 0.72 \mathrm{~d}$ & $569.0 \pm 15.07 b$ & $11.85 \pm 1.02 \mathrm{bc}$ & $427.8 \pm 41.47 \mathrm{~d}$ \\
\hline $\mathrm{CA}$ & $45.94 \pm 3.12 b c$ & $265.00 \pm 8.46 \mathrm{~b}$ & $13.63 \pm 0.36 a$ & $637.2 \pm 37.20 \mathrm{ab}$ & $13.13 \pm 0.79 b c$ & $633.6 \pm 39.53 b$ \\
\hline $\mathrm{CA}+\mathrm{ASc}$ & $39.41 \pm 2.64 \mathrm{~cd}$ & $198.30 \pm 5.82 d$ & $12.59 \pm 0.44 \mathrm{ab}$ & $642.7 \pm 25.87 \mathrm{ab}$ & $9.83 \pm 0.85 \mathrm{c}$ & $411.0 \pm 6.02 \mathrm{~d}$ \\
\hline CA+NPASc & $44.02 \pm 2.05 b c$ & $192.30 \pm 13.12 \mathrm{~d}$ & $12.65 \pm 0.38 \mathrm{ab}$ & $552.9 \pm 36.10 \mathrm{~b}$ & $10.91 \pm 1.9 \mathrm{bc}$ & $374.0 \pm 33.94 \mathrm{~d}$ \\
\hline DM & $55.44 \pm 4.92 b$ & $283.40 \pm 9.48 \mathrm{ab}$ & $14.75 \pm 0.67 \mathrm{a}$ & $672.8 \pm 38.95 \mathrm{a}$ & $17.35 \pm 1.74 \mathrm{a}$ & $520.9 \pm 11.03 \mathrm{c}$ \\
\hline $\mathrm{DM}+\mathrm{CA}$ & $51.03 \pm 1.93 b$ & $293.20 \pm 5.70 a$ & $14.52 \pm 1.39 \mathrm{a}$ & $680.9 \pm 28.60 \mathrm{a}$ & $13.74 \pm 0.50 \mathrm{~b}$ & $639.0 \pm 33.66 \mathrm{~b}$ \\
\hline $\mathrm{DM}+\mathrm{CA}+\mathrm{ASc}$ & $39.98 \pm 2.65 \mathrm{~cd}$ & $234.00 \pm 8.42 \mathrm{c}$ & $10.35 \pm 0.50 \mathrm{bc}$ & $703.6 \pm 27.27 \mathrm{c}$ & $10.75 \pm 0.91 b c$ & $811.5 \pm 16.79 \mathrm{a}$ \\
\hline $\mathrm{DM}+\mathrm{CA}+\mathrm{NPASc}$ & $40.79 \pm 0.86 \mathrm{~cd}$ & $212.2 \pm 7.33 \mathrm{~cd}$ & $9.92 \pm 1.23 \mathrm{c}$ & $559.2 \pm 31.93 \mathrm{~b}$ & $10.84 \pm 0.86 b c$ & $637.9 \pm 24.47 \mathrm{~b}$ \\
\hline
\end{tabular}

Values are expressed as mean \pm SEM. Values are expressed as mean \pm SEM. Different letters indicate significant difference among groups $(\mathrm{p}<0.05$, ANOVADuncan's test). ADA (U/L/mg of protein); NOx ( $\mu \mathrm{mol} / \mathrm{L})$.

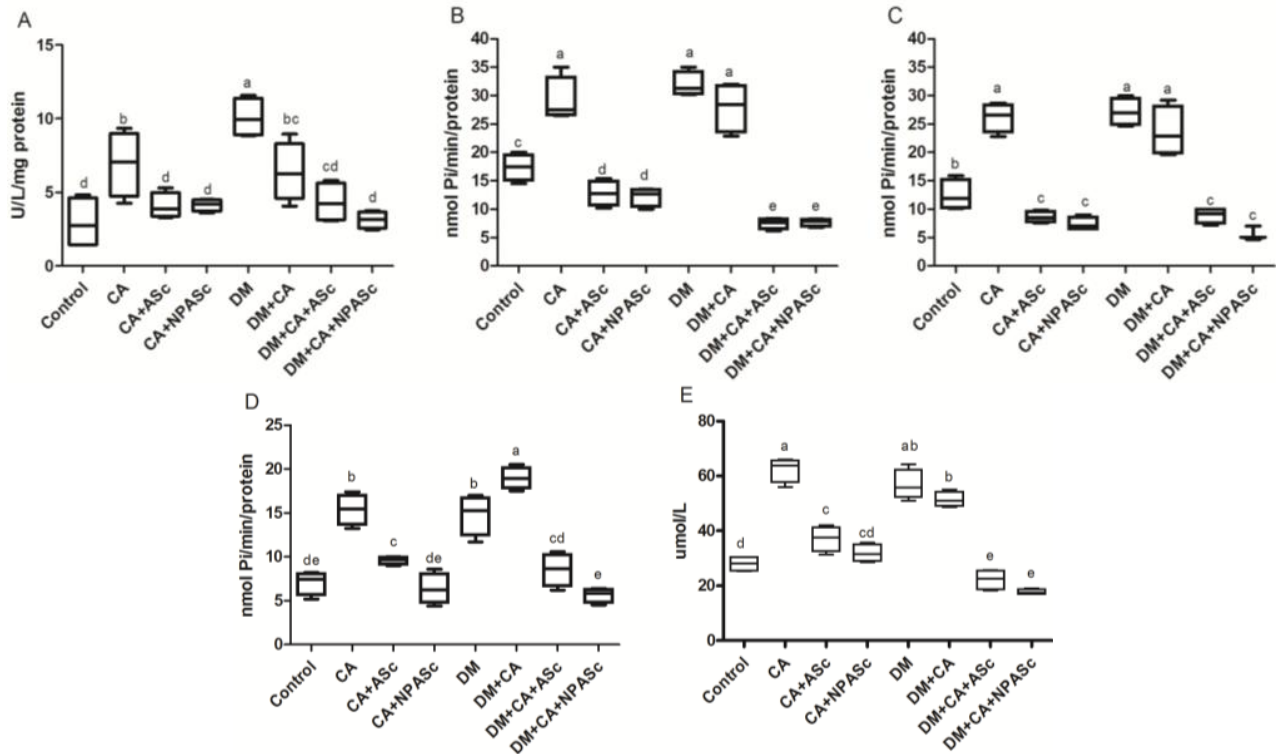

Fig. 3: NTPDase using ATP and ADP and 5'NT using AMP activities and NO levels in platelets of control, diabetic and/or C. albicans-infected rats treated or not with ASc or NPASc. Values are expressed as mean \pm SEM. Different letters indicate significant difference among groups ( $\mathrm{p}<0.05$, ANOVA-Duncan's test). A= ADA (U/L); B= AMP, C= ADP (nmol Pi/min/protein); $\mathrm{D}=\mathrm{ATP}(\mathrm{nmol} \mathrm{Pi} / \mathrm{min} /$ protein) and $\mathrm{E}=\mathrm{NO}(\mu \mathrm{mol} / \mathrm{L})$.

\section{ADA, 5'-NT and NTPDase activities and NO levels in platelets}

Similarly to the effects observed in serum, ADA, 5'-NT and NTPDase activities were also increased in platelets of DM and/or $C$. albicans-infected animals. The enzymatic activities were decreased in the groups treated with ASc and NPASc. Likewise, NO levels were also increased in DM, CA, and DM+CA, but the treatment was only able to normalize NO levels in CA+NPASc (Fig. 3).

\section{ADA and NO in tissues}

ADA activity was increased in animals with DM and/or infected with $C$. albicans, mainly in the kidney and liver. Kidney and liver ADA activities in DM animals infected with $C$. albicans and treated with ASc $(\mathrm{DM}+\mathrm{CA}+\mathrm{ASc})$ or NPASc $(\mathrm{DM}+\mathrm{CA}+\mathrm{NPASc})$ were decreased when compared to the respective control (DM+CA) (Table 3). This effect was not observed in non-diabetic rats infected with $C$. albicans and treated with ASc $(\mathrm{CA}+\mathrm{ASc})$ or NPASc $(\mathrm{DM}+\mathrm{CA}+\mathrm{NPASc})$. Pancreas ADA activity did not differ among groups, except for the significant increase observed in DM $(\mathrm{p}<0.01)$. Kidney NO levels were also increased in rats with DM and/or C. albicans infection in comparison to the control group. Groups treated with ASc $(\mathrm{CA}+\mathrm{ASc}$ and $\mathrm{DM}+\mathrm{CA}+\mathrm{ASc})$ and NPASc $(\mathrm{CA}+\mathrm{NPASc}$ and $\mathrm{DM}+\mathrm{CA}+\mathrm{NPASc}$ ) showed a significant decrease in kidney NO levels in comparison to their respective controls (CA and $\mathrm{DM}+\mathrm{CA})$. In the liver, an increase in NO levels was observed in $\mathrm{DM}$ and $\mathrm{CA}$, and the treatment with $\mathrm{ASc}(\mathrm{DM}+\mathrm{CA}+\mathrm{ASc})$ and NPASc (DM+CA+NPASc) had effect when compared to DM+CA $(p<0.01)$. Finally, an increase in NO levels was observed in the pancreas of animals in DM, CA and DM+CA groups when compared to the control group. The treatment was only effective in $\mathrm{CA}+\mathrm{ASc}$ and $\mathrm{CA}+\mathrm{NPASc}$ when compared with CA.

\section{In vivo antifungal activity}

Fungal tissue burden counts in kidney and liver were of $10.25 \pm 0.85 \mathrm{CFU} / \mathrm{g}$ and $2.53 \pm 0.39 \mathrm{CFU} / \mathrm{g}$ (CA) and of $13.25 \pm 1.25$ and 3.66 $\pm 0.8 \mathrm{CFU} / \mathrm{g}(\mathrm{DM}+\mathrm{CA})$, respectively. Kidney and liver of rats treated with ASc showed fungal load of $9.5 \pm 0.5$ and $2.5 \pm 0.5$ $\mathrm{CFU} / \mathrm{g} \quad(\mathrm{CA}+\mathrm{ASc})$ and $12.25 \pm 1.01$ and $2 \pm 0.57 \mathrm{CFU} / \mathrm{g}$ $(\mathrm{DM}+\mathrm{CA}+\mathrm{ASc})$, respectively. Kidney and liver of rats treated with NPASc showed fungal load of $7.3 \pm 0.5$ and $2 \pm 0.1 \mathrm{CFU} / \mathrm{g}$ $(\mathrm{CA}+\mathrm{NPASc})$ and $11 \pm 2.05$ and $1.25 \pm 0.25 \mathrm{CFU} / \mathrm{g}$ 
$(\mathrm{DM}+\mathrm{CA}+\mathrm{NPASc})$, respectively. No fungi were recovered from animals not infected by C. albicans (control and DM).

\section{DISCUSSION}

We examined the metabolic changes in a short-term DM model with $C$. albicans infection, their association with inflammatory changes and disturbances in adenine nucleosides and nucleotides and the treatment with $S$. cumini seeds in the form of extract and polimeric nanoparticles. DM promoted an increase in 5 -NT and NTPDase activities in serum and platelets as a response to metabolic insult, which is in agreement with other studies (Lunkes et al., 2003; Lunkes et al., 2004; Schmatz et al., 2013). Curiously, the animals inoculated with $C$. albicans also showed an increase in ATP, ADP and AMP hydrolysis in serum and platelets, contributing to an increase in adenosine production. This was accompanied by an increase in ADA activity, which could be related to an attempt of the organism to compensate organic alterations such as the high levels of ATP released during inflammation, leading to an increase in adenosine deamination. In line with the enhancement of ectonucleotidase activities in serum and platelets, ADA activity was increased in kidney, liver and pancreas of DM animals, corroborating previous studies (Schmatz et al., 2009; Bitencourt et al., 2015). An increase in ADA activity was also observed in the same organs of $C$. albicans-infected animals. The decrease in adenosine levels is likely to contribute to a high inflammatory state well-known in DM, with increased release of pro-inflammatory cytokines (IL-1, IL-6, TNF- $\alpha$ and IFN- $\mathrm{y}$ ) and $\mathrm{NO}$, as observed in DM, CA and DM+CA groups. These groups also showed increased ADA and DPPIV activities in lymphocyte suspension. This may be related to the interaction of ADA and DPPIV on $\mathrm{T}$ cells, resulting in costimulatory signs responsible for the activation of the T-cell receptor, presenting an important role in immune responses (Gorrell et al., 2001; Elgün $e t$ al., 2001).

Taken together, these findings indicate that the upregulation of ectoenzymes in serum and lymphocytes, which reflects in the immune system, and in the platelets, an important source of nucleotides and nucleosides, may play important roles in (1) controlling cellular responses induced by diabetes complications and (2) attenuating systemic changes caused by the fungal infection (Schmatz et al., 2013; Idzko et al., 2014). An important finding of this study was that both ASc and NPASc were able to reduce 5'-NT, NTPDase and ADA activities in cells and serum, and thus facilitating the regulation of the immune system for assisting the host response in an attempt to control the inflammation caused by DM and C. albicans. Moreover, ASc and NPASc decreased the activity of this enzyme in the kidney and liver of the treated groups, thus modulating adenosine concentrations. This effect is highly relevant, since adenosine has been proven to play an important role in the modulation of insulin action on glucose metabolism in different tissues and to reduce inflammation and tissue injury (Rutkiewicz and Górski, 1990;
Cuzzocrea et al., 2000). The model of candidiasis used in the present experiment is a sub-acute systemic infection that is usually well tolerated by the animals for several weeks, is not cleared spontaneously and mimics human infection (Fisher et al., 1989). Therefore, as expected, we observed an increase in proinflammatory cytokines in the group infected with $C$. albicans. Moreover, hyperglycemia is known to increase the production of free radicals and to induce inflammation, which can lead to a permanent stimulation of immune cells (Buchta et al., 2013; Kim et al., 2014).

This is in agreement with the extremely strong inflammatory response observed in DM rats infected with $C$. albicans. Nonetheless, ASc and NPASc were able to decrease the levels of pro-inflammatory cytokines and to increase the levels of the anti-inflammatory cytokine IL-10, attenuating the deleterious effects of the exacerbated inflammatory response. These results are likely to be related to the modulation of ectonucleotidase activities by S. cumini, reflecting in the increase of extracellular adenosine and, consequently, regulating host immune responses. Moreover, secondary metabolites of $S$. cumini extract have been reported to block the activation of nuclear factor kappa B (NF- $\mathrm{KB})$, a proinflammatory transcription factor that leads to activation of inflammatory mediators in several pathologies (Donepudi et al., 2012; Swami et al., 2012).

The antifungal activity of $S$. cumini in vitro is still quite controversial (Chandrasekaran and Venkatesalu, 2004; Shad et al., 2014), possibly due to different concentrations of phytochemical compounds present in extract formulations of plants obtained from different geographical areas. Previously, we have reported that gallic and chlorogenic acids, compounds which are present in greater quantities in the extract, showed low or no antifungal activity against fungi when evaluated alone. Notwithstanding, the formulations containing the whole extract, ASc and NPASc, showed increased antifungal activity in vitro, demonstrating a synergistic effect when the compounds are used together (Bitencourt et al., 2016).

Here we observed that DM rats had higher fungal burden than non-diabetic. No antifungal activity was observed for ASc, but liver and kidney of rats treated with NPASc showed lower fungal burden in comparison to controls. The antifungal activity, associate with the immune response developed by the animals, support the hypothesis that the anti-inflammatory activity of the extract in vivo is more prominent than the antifungal activity. To the authors' knowledge, this is the first study evaluating the effects of $S$. cumini in DM rats with candidiasis.

The role that host-derived ACh plays in modulating the growth and pathogenicity of microorganisms is unclear. We observed an increase in AChE activity in lymphocyte suspensions in DM, CA and DM+CA groups. ASc and NPASc were equally able to decrease the activity of AChE in DM+CA+ASc and $\mathrm{DM}+\mathrm{CA}+\mathrm{NPASc}$, increasing ACh levels, which has recently been shown to be an inhibitor of $C$. albicans biofilm formation and pathogenicity (Rajendran et al., 2015). 
Indeed, ACh has anti-inflammatory properties that could have modulated the immune responses in the rats, contributing to increase IL-10 levels. In line with Helmstadter (2008), we observed a hypoglycemic effect in the animals treated with ASc, but NPASc treatment was able to reduce the glucose more effectively, probably because of its capacity to normalize insulin levels. PCL polymer has been used in the development of nanoparticulate systems of natural products and has presented several advantages such as maintaining the antioxidant capacity, bioavailability, solubility and stability of polyphenols (Sanna et al., 2015; Ng et al., 2015). Consequently, it can promote an improvement of the known pharmacological activity of these substances such as stimulating insulin secretion from the remaining $\beta$-cells and mimicking insulin activity, resulting in peripheral glucose uptake (Ayyanar et al., 2013).

The effects of STZ on $\beta$-cells may be mediated by local liberation of NO from STZ within islets, contributing to a part of its diabetogenic potential and exaggerating $\beta$-cell necrosis (Turk et al., 1993). In fact, other studies have reported an increased NO concentration in serum and tissues (Yang et al., 2014; Sokolovska et al., 2015; Varsha et al., 2015) and inducible nitric oxide synthase (iNOS) overexpression in STZ-induced diabetic rats (AlRejaie et al., 2015). In this context, we observed an increase in NO levels not only in pancreas, but also in the liver and kidneys of DM and/or C. albicans-infected animals, which can be related to the fact that besides of the enhancement in interactions of superoxide with NO in the oxidative diabetic environment, NO is involved in pathogen killing mechanism and contributes to damage in other tissues (Shahani and Sawa, 2011; Samarghandian et al., 2013). The higher effect of NPASc in decreasing the levels of NO in tissues in comparison to ASc can be attributed to the physicochemical characteristics of nanoparticles that can facilitate crossing membranes and interacting more effectively (Jain and Kumar, 2010). A second advantage of this formulation is its high capacity to encapsulate not only hydrophilic but also lipophilic compounds such as rutin and quercitin, which have important pharmacological actions and can be adsorbed in the polymeric wall. In addition, this system provides greater protection against oxidation and other degrading reactions that occurs in the initial segments of intestine, where phenolic substances present in the extract have major absorption (Mora-Huertas, 2010; Ferriz and Vinová, 2010; Bonifácio et al., 2014).

\section{CONCLUSION}

In conclusion, the involvement of ectonucleotidases during infections has been described for several microorganisms. However, there is little information on how these enzymes would contribute to the understanding of pathological condition in fungal infections. Rats with DM and/or Candida infection showed increased levels of ectonucleotidases and pro-inflammatory cytokines. ASc and NPASc were able to attenuate hyperglycemia and to prevent the increase in cytokine levels and in ectonucleotidase and $\mathrm{AChE}$ activities. As purines are recognized for their important role in modulating processes linked to inflammation, this may take action to regulate cytokine levels which in turn helped to decrease NO levels. Thus, we suggest that the modulation of ectoenzyme activities can be one of the mechanisms by which $S$. cumini act on cytokines that affect the development of chronic complications of DM. Of note, since NPASc was able to maintain the properties of the crude extract, this drug delivery system may be used for other hydrophilic drugs of medicinal plant origin.

\section{ACKNOWLEDGMENT}

Financial support and sponsorship: The authors wish to thank the Conselho Nacional de Desenvolvimento Científico e Tecnológico (CNPq-Pq303245/2014-0). The first author acknowledges the fellowship from the Coordenação de Aperfeiçoamento de Pessoal de Nível Superior (CAPES).

Conflict of Interests: There are no conflicts of interest.

\section{REFERENCES}

Al-Rejaie SS, Aleisa AM, Abuohashish HM, Parmar MY, Ola MS, Al-Hosaini AA, Ahmed MM. Naringenin neutralises oxidative stress and nerve growth factor discrepancy in experimental diabetic neuropathy. Neurol Res, 2015; 37: 924-933.

Ayyanar M, Subash-Babu P, Ignacimuthu S. Syzygium cumini (L.) Skeels., a novel therapeutic agent for diabetes: folk medicinal and pharmacological evidences. Complement. Ther Med, 2013; 21: 232-43.

Bitencourt PER, De Bona KS, Cargnelutti LO, Bonfanti G, Pigatto A, Boligon A, Athayde ML, Pierezan F, Zanette RA, Moretto MB. Syzygium cumini seed extract ameliorates adenosine deaminase activity and biochemical parameters but does not alter insulin sensitivity and pancreas architecture in a short-term model of diabetes. J Complement. Integr Med, 2015; 12: 187-193.

Bitencourt PER, Ferreira LM, Cargnelutti LO, Denardi L, Boligon A, Fleck M, Brandão R, Atahyde ML, Cruz L, Zanette RA, Alvez $\mathrm{SH}$, Moretto MB. A new biodegradable polymeric nanoparticle formulation containing Syzygium cumini: Phytochemical profile, antioxidant and antifungal activity and in vivo toxicity. Ind Crops Prod, 2016; 83: 400-407.

Borovikova LV, Ivanova S, Zhang M, Yang H, Botchkina GI, Watkins LR, Wang H, Abumrad N, Eaton JW, Tracey KJ. Vagus nerve stimulation attenuates the systemic inflammatory response to endotoxin. Nature, 2000; 405: 458-462.

Boteanu RM, Uyy E, Suica VI, Antohe F. High-mobility group box 1 enhances the inflammatory process in diabetic lung. Arch Biochem Biophys, 2015; 6: 55-64.

Bonifácio BV, Silva PBD, Ramos MADS, Negri KMS, Bauab TM, Chorilli M. Nanotechnology-based drug delivery systems and herbal medicines: a review. Int J Nanomed, 2014; 9: 1-15.

Buchta V, Matula V, Kestřánek J, Vejsová M, Křivčíková L, Špaček J. Je diabetes mellitus rizikový factor kvasinkového poševního zánětu? Is diabetes mellitus a risk factor in genital yeast infections? Česká Gynekol, 2013; 78: 537-544.

BRASIL. Ministério da Saúde. Portal da Saúde: Programa Nacional de Plantas Medicinais e Fitoterápicos. 2009. Avaiable at: http://portalsaude.saude.gov.br/images/pdf/2015/janeiro/05/programa

nacional-plantas-medicinais-fitoter--picos-pnpmf.pdf [Accessed: Fev de 2016].

Chan KM, Delfert D, Junger KD. A direct colorimetric assay for Ca+2- stimulated ATPase activity. Anal Biochem, 1986; 157: 375-380.

Chandrasekaran M, Venkatesalu V. Antibacterial and antifungal activity of Syzygium jambolanum seeds. J Ethnopharmacol, 2004; 91: 105-108. 
Cuzzocrea S, Mazzon E, Calabro G, Dugo L, De Sarro A, van De LOO FA, Caputi AP. Inducible nitric oxide synthase knockout mice exhibi t resistance to pleurisy and lung injury caused by carrageenan. Am J Respir Crit Care Med, 2000; 162: 1859-1866.

Da Silva NC, Regis ACD, Esquibel MA, Santos JES, Almeida MZ. Uso de plantas medicinais na comunidade quilombola da Barra II Bahia, Brasil. Boletin Latinoamericano y del Caribe de Plantas Medicinales y Aromáticas, 2012; 11: 435-453.

De Bona KS, Bonfanti G, Bitencourt PE, Cargnelutti LO, Da Silva TP, Zanette RA, Pigatto AS, Moretto M. Syzygium cumini is more effective in preventing the increase of erythrocytic ADA activity than phenolic compounds under hyperglycemic conditions in vitro. J Physiol Biochem, 2014; 70: 321-30

Donepudi AC, Aleksunes LM, Driscoll MV, Seeram NP, Slitt AL. The traditional Ayuverdic medicine, Eugenia Jambolana (Jamun Fruit) decreases liver inflammation, injury, and fibrosis during cholestasis. Liver Int, 2012; 32: 560-573.

Ellman GL, Courtney DK, Andres V, Feather-Stone RM. A new and rapid colorimetric determination of acetylcholinesterase activity. Biochem Pharmacol, 1961; 7: 88-95.

Elgün S, Keskinege A, Yılmaz E. Tissue dipeptidyl peptidase IV and adenosine deaminase activities in benign prostatic hypertrophyand prostate cancer. Cancer Res Ther Control, 2001: 11: 107-11.

Ferriz JM, Vinová J. Prodrug design of phenolic drugs. Curr Pharm Des, 2010; 16: 4491-4499.

Fisher MA, Lee PG, Tarry WF. Fluconazole (UK-49,858) treatment of candidiasis in normal and diabetic rats. Antimicrob Agents Chemother, 1989; 33: 1042-1045.

Fraga-Silva TF, Marchetti CM, Mimura LA, Locachevic GA, Golim MA, Venturini J, Arruda MS. Relationship among short and long term of hypoinsulinemia-hyperglycemia, dermatophytosis, and immunobiology of mononuclear phagocytes. Mediators Inflamm, $2015 ; 342345$.

Giusti G, Galanti B, 1984. Colorimetric method. In: Bergmeyer HU, editor. Methods of enzymatic analysis. Weinheim: Verlag Chemie, $315-23$.

Gorrell MD, Gysbers V, McCaughan GW. CD26: a multifunctional integral membrane and secreted protein of activated lymphocytes. Scand. J Immunol, 2001; 54: 249-264.

Helmstadter A. Syzygium cumini (L.) SKEELS (Myrtaceae) against diabetes-125 years of research. Die Pharmazie, 2008; 63: 91-101.

Idzko M, Ferrari D, Riegel AK, Eltzschig H. Extracellular nucleotide and nucleoside signaling in vascular and blood disease. Blood, 2014; 124: 1029-1037.

Jain JP, Kumar N. Development of amphotericin B loaded polymersomes based on (PEG)3-PLA co-polymers: Factors affecting size and in vitro evaluation. Eur J Pharm Sci, 2010; 40: 456-465.

Jarmołowska B, Bielikowicz K, Iwan M, Sidor K, Kostyra E, Kaczmarski M. Serum activity of dipeptidyl peptidase IV (DPPIV; EC 3.4.14.5) in breast-fed infants with symptoms of allergy. Peptides, 2007; 28: $678-82$.

Joshi N, Caputo GM, Weitekamp MR, Karchmer AW. Infections in patients with diabetes mellitus. N Engl J Med, 1999; 341: 1906-1912.

Kameoka J, Tanaka T, Nojima Y, Schlossman SF, Morimoto C. Direct association of adenosine deaminase with a $\mathrm{T}$ cell activation antigen, CD26. Science, 1993; 261: 466-9.

Kim JS, Lee YH, Kim JC, Ko YH, Yoon CS, Yi HK. Effect of exercise training of different intensities on anti-inflammatory reaction in streptozotocin-induced diabetic rats. Biol Sport, 2014; 31: 73-79.

Lowry OH, Rosebrough NJ, Farr AL, Randall RJ. Protein measurement with the folin phenol reagent. J Biol Chem, 1951; 193: $265-$ 75.

Lunkes G, Lunkes D, Stefanello F, Morsch A, Morsch V, Mazzanti C, Schetinger MR. Enzymes that hydrolyze adenine nucleotides in diabetes and associated pathologies. Thromb Res, 2003; 109: 189-194.

Lunkes GI, Lunkes DS, Morsch VM, Mazzanti CM, Morsch AL, Miron VR, Schetinger MR. NTPDase and 5'- nucleotidase activities in rats with alloxan-induced diabetes. Diabetes Res Clin Pract, 2004; 65: $1-6$.

Mora-Huertas CE, Fessi H, Elaissari A. Polymer-based nanocapsules for drug delivery. Int J of Pharmaceutics, 2010; 385: 113-14.

$\mathrm{Ng}$ YJ, Benson HAE, Brown DH, Chen Y. Synthesis and characterization of novel copolymeric resveratrol conjugates. J Chem, 2015; 1-6.

Oses JP, Cardoso CM, Germano RA, Kirst IB, Rucker B, Furstenau CR, Wink MR, Bonan CD, Battastini AM, Sarkis JJ. Soluble NTPDase: An additional system of nucleotide hydrolysis in rat blood serum. Life Sci, 2004; 74: 3275-3284

Prince PS, Menon VP, Pari L. Hypoglycemic activity of Syzygium cumini seeds: effect on lipid peroxidation in alloxan diabetic rats. J Ethnopharmacol, 1998; 61: 1-7.

Quintanar-Guerrero D, Alleman E, Doelker E, Fessi H Preparation and characterization of nanocapsules from preformfed polymers by new process based on emulsification-diffusion technique. Pharm Res, 1998; 15: 1056-1062.

Rajendran R, Borghi E, Falleni M, Perdoni F, Tosi D, Lappin DF, O’Donnell L, Greetham D, Ramage G, Nile C. Acetylcholine protects against Candida albicans infection by inhibiting biofilm formation and promoting hemocyte function in a Galleria mellonella infection model Eukaryot Cell, 2015; 14: 834-844.

Rutkiewicz J, Górski J. On the role of insulin in regulation of adenosine deaminase activity in rat tissues. FEBS Lett, 1990; 271: 79-80.

Sai Ram M, Sharma SK, Ilavazhagan G, Kumar D, Selvamurthy W. Immunomodulatory effects of NIM- 76, a volatile fraction fromneemoil. J Ethnopharmacol, 1997; 55: 133-139.

Samadder A, Das S, Das J, Paul A, Khuda-Bukhsh AR. Ameliorative effects of Syzygium jambolanum extract and its poly (lacticco-glycolic) acid nano-encapsulated form on arsenic induced hyperglycemic stress: a multi-parametric evaluation. J Acupunct Meridian Stud, 2012; 5: 310-8

Samarghandian S, Borji A, Delkhosh MB, Samini F. Safranal treatment improves hyperglycemia,hyperlipidemia and oxidative stress in streptozotocin-induced diabetic rats. J Pharm Pharm Sci, 2013; 16: 352 362.

Sanna V, Lubinu G, Madau P, Pala N, Nurra S, Mariani A, Sechi M. Polymeric nanoparticles encapsulating white tea extract for nutraceutical application. J Agric Food Chem, 2015; 63: 2026-32.

Schmatz R, Schetinger MR, Spanevello RM, Mazzanti CM, Stefanello N, Maldonado PA, Gutierres J, Corrêa M de C, Girotto E, Moretto MB, Morsch VM. Effects of resveratrol on nucleotide degrading enzymes in streptozotocin induced diabetic rats. Life Sci, 2009; 84: 345-350.

Schmatz R, Mann TR, Spanevello R, Machado MM, Zanini D, Pimentel VC, Stefanello N, Martins CC, Cardoso AM, Bagatini M, Gutierres J, Leal CA, Pereira LB, Mazzanti C, Schetinger MR, Morsch VM. Moderate red wine and grape juice consumption modulates the hydrolysis of the adenine nucleotides and decreases platelet aggregation in streptozotocin-induced diabetic rats. Cell Biochem Biophys, 2013; 65 129-43.

Schön E, Demuth HU, Barth A, Ansorge S. Dipeptidyl peptidase IV of human lymphocytes. Evidence for specific hydrolysis of glycylproline p-nitroanilide in T-lymphocytes. Biochem J, 1984; 223: 2558 .

Shad AA, Ahmad S, Ullah R, AbdEl-Salam NM, Fouad H, Rehman NU, Hussain H, Saeed W. Phytochemical and Biological Activities of Four Wild Medicinal Plants. Scientific World Journal, 2014.

Shahani N, Sawa A. Nitric oxide signaling and nitrosative stress in neurons: role for S-nitrosylation. Antioxid Redox Signal, 2011; 14 1493-1504.

Sokolovska J, Isajevs S, Rostoka E, Sjakste T, Trapina I, Osina K, Paramonova N, Sjakste N. Changes in glucose transporter expression and nitric oxide production are associated with liver injury in diabetes. Cell Biochem Funct, 2015; 33: 366-374. 
Swami SB, Thakor NSJ, Patil MM, Haldankar PM. Jamun (Syzygium cumini (L.)): A Review of Its Food and Medicinal Uses. Food and Nutrition Sciences, 2012; 3: 1100-1117.

Tatsch E, Bochi GV, Pereira RS, Kober H, Agertt VA, de Campos MM, Gomes P, Duarte MM, Moresco RN. A simple and inexpensive automated technique for measurement of serum nitrite/nitrate. Clin Biochem, 2011; 44: 348-350.

Turk J, Corbett JA, Ramanadham S, Bohrer A, McDaniel ML. Biochemical evidence for nitric oxide formation from streptozotocin in isolated pancreatic islets. Biochem Biophys Res Commun, 1993; 197: $1458-1464$

Varsha S, Raman T, Manikandan R, Dhanasekaran G. Hypoglycemic action of vitamin K1 protects against early-onset diabetic nephropathy in streptozotocin-induced rats M.K.N. Nutrition, 2015; 31: 1284-1292.

Vizzotto M C, Pereira M C. Caracterização das propriedades funcionais do jambolão. Embrapa Clima Temperado. Boletim de Pesquisa e Desenvolvimento, 2008; 79: 1-26.
Yang SJ, Lee J, Kim WEA, Dal Nam K, Hahn HG, Young Choi S, Cho SW. Effects of N-adamantyl-4-methyl thiazol-2-amine on hyperglycemia, hyperlipidemia and oxidative stress in streptozotocininduced diabetic rats. Eur J Pharmacol, 2014; 736: 26-34.

\section{How to cite this article:}

Bitencourt PER, Cargnelutti LO, Stein CS, Lautenchleger R, Ferreira LM, Sangoi M, Boligon A, Duarte MMMF, Moresco RN, Cruz L, Zanette RA, Alves SH, Moretto MA. Anti-inflammatory action of seed extract and polymeric nanoparticles of Syzygium cumini in diabetic rats infected with Candida albicans. J App Pharm Sci, 2017; 7 (01): 007-016. 